\title{
Newborn screening as a system from birth through lifelong care
}

\author{
Linda L. McCabe, PhD $D^{I}$ and Edward R. B. McCabe, MD, PhD
}

$\mathrm{T}$ The American Academy of Pediatrics Newborn Screening Task Force ${ }^{1}$ called for a national agenda for state newborn screening programs. The Task Force members recognized that newborn screening was far more than the collection of blood from newborns on filter paper blotters, shipping the blotters to the state newborn screening lab, testing in the laboratory, and reporting the results of the screening test. They emphasized the importance of diagnosis, timely initiation of treatment and longterm follow-up within the context of a medical home and a subspecialty center. They recommended that there be a rational basis for the addition of new tests and a move to uniformity across states in the tests included. They encouraged parents and community members to be involved in newborn screening policy development.

Hinman et al. $^{2}$ in this issue describe a health informatics approach to identify the information systems required to coordinate both the public health care and clinical care of individuals with a positive newborn screen. Such a system would go a long way toward the recommendations of the American Academy of Pediatrics Newborn Screening Task Force. ${ }^{1}$ The information systems could also, for example, be used to link the physiological newborn hearing screening with the dried blood blotter to facilitate mutation analysis that would provide definitive diagnosis and intervention. ${ }^{3-6}$

In the United States, 4.2 million newborns receive between nine and 54 newborn screening tests each year. Each state has a different number of tests and the tests that are performed vary from one state to the other. Newborn screening represents the highest volume of genetic testing historically, currently, and for the foreseeable future. Therefore, newborn screening represents an excellent model as we look ahead to personalized medicine. ${ }^{7}$ The Hinman et al. ${ }^{2}$ information systems could provide useful models for genomic medicine.

Another important aspect of the coordination through information systems technology suggested by Hinman et al. ${ }^{2}$ would be the integration of primary and secondary screening using the initial blood blotter. ${ }^{8-12}$ A two-tiered newborn screening strategy was first used for congenital hypothyroidism, evaluating thyroxine $\left(\mathrm{T}_{4}\right)$ first. If the $\mathrm{T}_{4}$ was low, testing the level of thyroid-stimulating hormone was performed. ${ }^{8}$ This approach was more cost-effective than routinely performing both tests on every newborn. In addition, sensitivity was improved while not decreasing specificity. ${ }^{8}$ Two-tiered testing is also used with

From the ${ }^{1}$ Department of Human Genetics, David Geffen School of Medicine, and ${ }^{2}$ Mattel Children's Hospital, UCLA, Los Angeles, California.

Edward R. B. McCabe, MD, PhD, Mattel Children's Hospital, UCLA, 10833 Le Conte Ave., Los Angeles, CA 90095-1752. E-mail: emccabe@mednet. ucla.edu.

The authors declare no conflict of interest.

Submitted for publication March 23, 2009

Accepted for publication March 24, 2009.

Published online ahead of print April 25, 2009.

DOI: 10.1097/GIM.0b013e3181a6dcf0 hemoglobinopathy screening, where a positive protein phenotype result triggers DNA genotyping. ${ }^{8-10}$ A similar strategy was proposed for severe combined immunodeficiency. ${ }^{11}$ Severe combined immunodeficiency newborn screening would include determination of a biomarker, such as interleukin-7 (a T-cell growth cytokine) and T-cell receptor excision circles (byproducts of T-cell receptor recombination).

Hinman et al. ${ }^{2}$ emphasize the importance of long-term follow-up. Long-term follow-up care is often a missing piece in state newborn screening programs. If states cover children with disorders discovered on newborn screening, coverage may end at 18 or 21 years of age. Insurance companies may not cover these disorders. As we have learned from maternal phenylketonuria (PKU), follow-up is just as important for an adult woman with PKU as for a child with PKU. Most medical geneticists provide care across the lifespan. Increasingly, pediatricians, family practitioners, and internists are working together to provide transition of care. ${ }^{13}$ Hinman et al. ${ }^{2}$ provide a model for coordination of long-term follow-up.

Hinman et al. ${ }^{2}$ emphasize the partnerships required for newborn screening systems to be effective and successful, including the families, health care providers, and community-based and public health system. They maintain that care coordination involving this complex network of service providers in different geographic locations spanning the life course with evolving knowledge about these diseases demands information systems. We argue that newborn screening is the "laboratory" in which we are preparing for personalized genomic medicine. ${ }^{5,7,8}$ As we move from disease-specific testing to expanded newborn screening with tandem mass spectrometry and anticipate the possibility of individuals' genomes, and perhaps their epigenomes, becoming newborn screening analytes, the volume of information and our ability to integrate and update the data analysis will require massive computational capacities as part of these information systems. Hinman et al. ${ }^{2}$ are not only providing us with critical insight into newborn screening systems but also are showing us the more comprehensive approach to systems analysis that will be necessary for successful implementation of personalized medicine.

\section{REFERENCES}

1. American Academy of Pediatrics Newborn Screening Task Force. Serving the family from birth to the medical home: newborn screening: a blueprint for the future: a call for a national agenda on state newborn screening programs. Pediatrics 2000;106:389S-427S

2. Hinman AR, Mann MY, Singh RH. Newborn dried bloodspot screening: mapping the clinical and public health components and activities. Genet Med 2009;11:418-424

3. McCabe LL, McCabe ERB. Newborn screening as a model for population screening. Mol Genet Metab 2002;75:299-307.

4. McCabe LL, Therrell BL, McCabe ERB. Newborn screening: rationale for a comprehensive, fully integrated public health system. Mol Genet Metab 2002;77:267-273

5. Khoury MJ, McCabe LL, McCabe ERB. Population screening in the age of genomic medicine. $N$ Engl J Med 2003;348:50-58

6. Schimmenti LA, Martinez A, Telatar M, et al. Infant hearing loss and connexin testing in a diverse population. Genet Med 2008;10:517-524.

7. McCabe LL, McCabe ERB. DNA: promise and peril. Berkeley, CA: University of California Press, 2008. 
8. McCabe LL, McCabe ERB. Expanded newborn screening: implications for genomic medicine. Annu Rev Med 2008;59:163-175.

9. Bhardwaj U, Zhang Y-H, Blackburn W, McCabe LL, McCabe ER. Rapid confirmation of Southeast Asian and Filipino $\alpha$-thalassemia genotypes from newborn screening specimens. Am J Hemat 2002;71:56-58.

10. Bhardwaj U, Zhang Y-H, Lorey F, McCabe LL, McCabe ER. Molecular genetic confirmatory testing from newborn screening samples for the common African-American, Asian Indian, Southeast Asian, and Chinese $\beta$-thalassemia mutations. Am J Hemat 2005;78:249-255.
11. McGhee SA, Stiehm ER, Cowan M, Krogstad P, McCabe ER. Two-tiered universal newborn screening strategy for severe combined immunodeficiency. Mol Genet Metab 2005;86:427-430.

12. Bhardwaj U, Zhang Y-H, McCabe ERB. Neonatal hemoglobinopathy screening: molecular genetic technologies. Mol Genet Metab 2003;80: $129-137$

13. Oeffinger KC, Mertens AC, Hudson MM, et al. Health care of young adult survivors of childhood cancer: a report from the Childhood Cancer Survivor Study. Ann Fam Med 2004;2:61-70. 